\title{
Effect of the granulometric characteristics of monensin sodium on controlling experimental coccidiosis in broiler chickens
}

\author{
Efeito das características granulométricas da monensina sódica no controle \\ da coccidiose experimental em frangos de corte
}

\author{
Luisa Rambozzi ${ }^{1 *}$; Manuela Renna ${ }^{2}$; Paolo Cornale ${ }^{2}$; Giovanni Perona ${ }^{3}$; Vanda Malfatto ${ }^{2}$; Antonio Mimosi ${ }^{2,3}$ \\ ${ }^{1}$ Dipartimento di Produzioni Animali, Epidemiologia ed Ecologia, Sezione Parassitologia, Università degli Studi di Torino \\ ${ }^{2}$ Dipartimento di Scienze Zootecniche, Università degli Studi di Torino \\ ${ }^{3}$ Centro Interdipartimentale Servizio Ricovero Animali, Università degli Studi di Torino
}

Received July 20, 2011

Accepted September 2, 2011

\begin{abstract}
The aim of the present study was to investigate the efficacy of monensin sodium grain size on controlling coccidiosis in broiler chickens. Three hundred and fifty Cobb 700 chicks were infected experimentally with $8 \times 10^{4}$ sporulated oocysts of Eimeria spp. The birds were fed with diets supplemented with powdered $(\mathrm{n}=150)$ or granulated $(\mathrm{n}=150)$ monensin, with particle sizes of $\leq 100 \mu \mathrm{m}$ and $450-650 \mu \mathrm{m}$, respectively. The remaining chicks $(\mathrm{n}=50)$ were used as an unmedicated control group. The birds' weights and number of oocysts per gram of litter in each group were recorded weekly. A total of 96 birds were randomly selected and culled during the trial. Their intestinal oocyst counts and lesion scores were determined. No significant differences in body weights were found between the groups at the end of the study. The percentages of infected animals, oocyst counts and lesion scores were significantly higher in the control group than in the other two groups; the two treated groups did not show any appreciable differences to each other. Enteritis was observed in 14 birds, all in the group supplemented with granulated monensin. These results suggest that powdered and granulated monensin have comparable efficacy in controlling coccidiosis in broiler chickens. However, treatments with monensin sodium of high grain size may be subject to contraindications relating to enteritis.
\end{abstract}

Keywords: Gallus gallus, coccidiostatic drug, Eimeria, particle size.

\section{Resumo}

O presente estudo teve como objetivo investigar a eficácia da monensina sódica com diferentes granulometrias no controle da coccidiose em frangos de corte. Trezentos e cinquenta pintos Cobb 700 foram infectados experimentalmente, utilizando-se $8 \times 10^{4}$ oocistos esporulados de Eimeria spp. As aves foram alimentadas com dietas suplementadas com monensina em pó $(\mathrm{n}=150)$ ou granulada $(\mathrm{n}=150)$, com partículas de dimensão $\leq 100 \mu \mathrm{m}$ e de $450-650 \mu \mathrm{m}$ respetivamente. As aves restantes $(\mathrm{n}=50)$ foram utilizadas como grupo controle náo sujeito a tratamento. $\mathrm{O}$ peso das aves e o número de oocistos por grama de material de cama de cada grupo foram avaliados semanalmente. Um total de 96 aves foi selecionado aleatoriamente e submetidos à eutanásia durante o período experimental. Nestas aves foram analisados o número de oocistos intestinais e o respectivo escore das lesôes. Não foram encontradas diferenças significativas relativas ao peso dos animais dos diferentes grupos no final do período experimental. A proporção de animais infectados, a quantidade de oocistos e o escore das lesóes foram significativamente superiores no grupo de controle, quando comparado com os dois grupos tratados, não encontrando diferenças significativas entre estes últimos. Foi observada enterite em 14 aves, pertencentes ao grupo suplementado com monensina granulada. Estes resultados indicam que a eficácia da monensina em pó e granulada é semelhante no controle de coccidiose em frangos de corte. No entanto, o tratamento com monensina sódica de elevada granulometria pode ser objeto de contraindicaçóes associadas à enterite.

Palavras-chave: Gallus gallus, droga coccidiostática, Eimeria, tamanho de partículas.

\footnotetext{
*Corresponding author: Luisa Rambozzi

Dipartimento di Produzioni Animali, Epidemiologia ed Ecologia,

Sezione Parassitologia, Università degli Studi di Torino, Via L. da Vinci 44,

10095 Grugliasco, TO, Italy

e-mail: luisa.rambozzi@unito.it
} 


\section{Introduction}

Poultry coccidiosis, caused by intracellular protozoan parasites of the genus Eimeria, is an important intestinal infection characterized by symptoms including diarrhea, weakness, drastic physiological damage, reduced feed conversion efficiency and, consequently, weight loss. Occurrences of coccidiosis in commercial poultry can range from 5 to $70 \%$ (DU; HU, 2004; FREITAS et al., 2008; AARTHI et al., 2010; LEE et al., 2010; TOLEDO et al., 2011), and economic losses have been widely reported (DALLOUL; LILLEHOJ, 2006).

There are basically two means of preventing coccidiosis: chemoprophylaxis and vaccination. While vaccination is today less applied in broiler production, also because of its higher cost, chemoprophylaxis using anticoccidials in the feed is by far the most popular method, insofar as it is estimated that $95 \%$ of broilers produced receive anticoccidials (CHAPMAN, 1999).

In the European Union, 11 coccidiostatic substances are currently authorized for prevention of coccidiosis in one or more animal species. Of the 40.65 million tonnes of feed produced annually for chickens, turkeys and rabbits, approximately 18.33 million tonnes are manufactured with the addition of a coccidiostat (IFAH, 2007). Feed business operators generally produce a broad range of products within a single feed plant. Several studies have shown that completely contamination-free production of premixes and compound feeds in existing multi-product plants is impossible in practice (KENNEDY et al., 1998; STRAUCH 2002a, b, 2003), thus resulting in cross-contamination of subsequent feed-batches.

Cross-contamination is a recognized problem, to the point that European Commission Directive 2009/8/EC recently amended a previous Directive 2002/32/EC (EUROPEAN COMMISSION, 2002, 2009) regarding the "[...] maximum levels of unavoidable carry-over of coccidiostats or histomonostats in non-target feed".

The physicochemical characteristics of coccidiostatic additives, such as their high dusting potential and adherence due to electrostatic charge, as well as the environmental conditions of production sites, can contribute towards cross-contamination (EFSA, 2008). Moreover, occupational exposure to monensin through accidental inhalation and/or dermal contact can represent potential negative health risks for workers (STORY; DOUBE, 2004).

Due to concerns regarding the use of anticoccidials, particularly about the potential for workers and non-target animals to be exposed to their residues, there is a constant search for innovative solutions. Granulated formulations of monensin sodium characterized by high particle size have been recently produced. Increasing the grain size can limit the dust emission from monensin sodium, consequently reducing the risks for handlers and those relating to cross-contamination throughout the feed chain.

The effect of drug particle size on dissolution rates and the corresponding drug absorption has been well established both theoretically and experimentally (FINCHER, 1968; KANENIWA; WATAKI, 1978; KANENIWA et al., 1978; HINTZ; JOHNSON, 1989; LU et al., 1993). For low to moderate-solubility drugs administered orally, like monensin sodium, a change in particle size can have a dramatic impact on their ability to be absorbed by the cell membranes (LIPINSKI, 2001, 2002).
The aim of this study was to investigate the efficacy of monensin sodium against coccidiosis in broiler chickens, according to its granulometric characteristics (powder vs. granules).

\section{Materials and Methods}

\section{Animals, diets and housing system}

The experiment lasted 42 days and was carried out at the experimental broiler farm of CISRA (Inter-Departmental Center for Animal Husbandry Services, University of Turin).

Three hundred and fifty one-day-old Cobb 700 male chicks were purchased from a local hatchery. On arrival at the experimental farm, they were divided into three groups, balanced according to body weight. The groups were allocated to different pens. The housing method was a litter system with a stocking density of eight birds per square meter. Before the birds were placed there, the pens were cleaned, washed, disinfected and provided with new wood shavings, in a layer of thickness $5 \mathrm{~cm}$. The ambient temperature was gradually decreased from $32{ }^{\circ} \mathrm{C}$ on the first day to $20^{\circ} \mathrm{C}$ at the end of the study. Ambient temperature and relative humidity were monitored at one-hour intervals.

Standard hygiene and prophylactic measures against infectious diseases were applied. All the broilers received a starter diet ( 0 to 2 weeks) and a finisher diet ( 3 to 5 weeks), and both were provided ad libitum (Table 1). Tap water was freely available. The diets were supplemented with $100 \mathrm{ppm}$ of powdered (particle size: $\leq 100 \mu \mathrm{m}$ ) monensin sodium (group $\mathrm{P}, \mathrm{n}=150$ ) or $100 \mathrm{ppm}$ of granulated (particle size: $450-650 \mu \mathrm{m}$ ) monensin sodium (group $\mathrm{G}, \mathrm{n}=150$ ). The remaining chicks (group $\mathrm{C}, \mathrm{n}=50$ ) did not receive any coccidiostat and they were used as an untreated positive control.

\section{Experimental infection}

The birds were experimentally infected at 5 days of age. A mixed coccidial inoculum of $3 \times 10^{4}$ sporulated oocysts of Eimeria acervulina, $2.5 \times 10^{4}$ of E. maxima and $2.5 \times 10^{4}$ of E. tenella per bird was administered with $1 \mathrm{~mL}$ of tap water directly into the crop by using a self-calibrated $1 \mathrm{~mL}$ micropipette. The challenge oocysts were isolated from naturally infected chickens. The oocysts, separated by using sieving and sedimentation techniques, were allowed to sporulate at $25^{\circ} \mathrm{C}$ in $2.5 \%$ potassium dichromate solution. The sporulated oocysts were cleared and counted using a modified McMaster technique (LONG; ROWELL, 1958).

\section{Sampling and measurements}

Separate working clothes, footwear and equipment were used for each pen throughout the experimental period in order to avoid cross-infection among groups.

During the trial, the broilers were individually weighed once a week in order to determine their weight gain.

Representative litter samples (a mixed sample of five handfuls taken in five sections per pen) were collected weekly from day 2 
Table 1. Experimental basal starter and finisher diets for broiler chickens.

\begin{tabular}{|c|c|c|}
\hline \multirow[t]{2}{*}{ Ingredients } & \multicolumn{2}{|c|}{ Diets (\% as fed) } \\
\hline & Starter & Finisher \\
\hline Decorticated toasted soybean meal & 38.91 & 18.01 \\
\hline Toasted soybean seeds & - & 15.00 \\
\hline Wheat meal & 27.47 & 55.54 \\
\hline Corn meal & 23.03 & 3.00 \\
\hline Animal-vegetable fat & 5.95 & 4.52 \\
\hline Dicalcium phosphate & 1.49 & 0.97 \\
\hline Calcium carbonate & 1.08 & 1.19 \\
\hline Vitamin $^{1}$ and mineral $^{2}$ premixes & 0.50 & 0.50 \\
\hline DL-methionine & 0.38 & 0.31 \\
\hline Butyric acid & 0.30 & - \\
\hline Salt & 0.29 & 0.22 \\
\hline L-lysine & 0.19 & 0.21 \\
\hline Phytase & 0.15 & 0.15 \\
\hline Sodium bicarbonate & 0.08 & 0.17 \\
\hline Choline chloride $(60 \%)$ & 0.07 & 0.07 \\
\hline Threonine & 0.06 & 0.09 \\
\hline Enzymes & 0.05 & 0.05 \\
\hline \multicolumn{3}{|l|}{ Calculated analysis } \\
\hline Crude protein (\%) & 23.80 & 21.00 \\
\hline Ether extract $(\%)$ & 8.20 & 8.90 \\
\hline Metabolizable energy $\left(\mathrm{MJ} \mathrm{kg}^{-1}\right)$ & 12.5 & 13.0 \\
\hline Crude fiber $(\%)$ & 3.00 & 3.20 \\
\hline Ashes (\%) & 5.80 & 5.20 \\
\hline Lysine (\%) & 1.45 & 1.25 \\
\hline Methionine (\%) & 0.70 & 0.60 \\
\hline Calcium (\%) & 1.05 & 0.95 \\
\hline Phosphorus (\%) & 0.80 & 0.71 \\
\hline Sodium $(\%)$ & 0.17 & 0.17 \\
\hline
\end{tabular}

${ }^{1}$ The vitamin premix in the starter diet contributed the following per kilogram of complete feed: vitamin $\mathrm{A}, 12,500 \mathrm{IU}$; vitamin $\mathrm{D}_{3}, 5,000 \mathrm{IU}$; vitamin $\mathrm{E}, 30 \mathrm{mg}$; thiamine, $3 \mathrm{mg}$; riboflavin, $6 \mathrm{mg}$; vitamin $\mathrm{B}_{6}, 3 \mathrm{mg}$; vitamin $B_{12}, 0.03 \mathrm{mg}$; vitamin C, $75 \mathrm{mg}$; vitamin $\mathrm{K}, 5 \mathrm{mg}$; niacin, $40 \mathrm{mg}$; folic acid, $0.75 \mathrm{mg}$; biotin, $0.20 \mathrm{mg}$; pantothenic acid, $20 \mathrm{mg}$. The vitamin premix in the finisher diet contributed the following per kilogram of complete feed: vitamin $\mathrm{A}, 12,500 \mathrm{IU}$; vitamin $\mathrm{D}_{3}$, 5,000 IU; vitamin $\mathrm{E}, 35 \mathrm{mg}$; thiamine, $2 \mathrm{mg}$; riboflavin, $4 \mathrm{mg}$; vitamin $\mathrm{B}_{6}, 2 \mathrm{mg}$; vitamin $\mathrm{B}_{12}, 0.02 \mathrm{mg}$; vitamin $\mathrm{K}$, $3.50 \mathrm{mg}$; niacin, $28 \mathrm{mg}$; folic acid, $0.50 \mathrm{mg}$; biotin, $0.15 \mathrm{mg}$. ${ }^{2}$ The trace mineral premix in the starter diet contributed the following per kilogram of complete feed: copper, $22.5 \mathrm{mg}$, manganese, $71.15 \mathrm{mg}$; iron, $78 \mathrm{mg}$; zinc, $75 \mathrm{mg}$; iodine, $0.98 \mathrm{mg}$; selenium, $0.27 \mathrm{mg}$; cobalt, $0.35 \mathrm{mg}$. The trace mineral premix in the finisher diet contributed the following per kilogram of complete feed: copper, 19.25; iron, 54.6; zinc, 52.5; iodine, $0.69 \mathrm{mg}$; selenium, $0.35 \mathrm{mg}$; cobalt, $0.25 \mathrm{mg}$; manganese, 49.8 .

post-infection to the end of the experiment. The mean number of oocysts per gram (OPG) of litter was calculated in accordance with the standard procedures of the World Association of Animal Veterinary Parasitology (WAAVP) (HOLDSWORTH et al., 2004).

Ninety-six chickens were randomly selected and euthanized on day 10 (six in groups P and G; two in group C), on day 25 after inoculation (18 in groups $\mathrm{P}$ and $\mathrm{G}$; five in group $\mathrm{C}$ ) and on day 37 after inoculation (18 in groups $\mathrm{P}$ and $\mathrm{G}$; five in group C), to evaluate pathological abnormalities. Intestinal lesions, if present, were investigated in accordance with the 0 to 4 scoring system proposed by Johnson and Reid (1970). The method covers a range of coccidial-specific lesions and is related to both the degree and the amount of intestine affected. The lesions were scored as follows: $0=$ lesions absent; $1=\mathrm{a}$ few scattered lesions; $2=$ a greater number of discrete lesions involving more of the affected zone of the intestine; 3 = lesions extensively developed with coalescence and some thickening of the intestinal walls; and $4=$ extensive coalescence of lesions with thickening of the wall and bloody intestinal contents. A microscope was used to examine scrapings for coccidia whenever there was doubt about the cause of a lesion.

In addition, the number of oocysts per gram of intestinal contents was individually recorded with regard to the same euthanized chickens.

Necropsies were performed on four chicks (1 P, 1 G, and 2 C) that died during the experiment. Neither the euthanized birds nor the birds that died were replaced.

The statistical analysis on the data was performed using the SPSS 16.0 software (SPSS, 2007). Weighted data were subjected to one-way analysis of variance (ANOVA). The non-parametric Kruskal-Wallis test was performed on the number of intestinal oocysts per gram of content and lesion scores; related post-hoc comparisons were performed using Mann-Whitney $U$ tests. Significance was declared at $\mathrm{p}<0.05$.

\section{Results and Discussion}

No significant differences in body weights were observed at the end of the trial among the three experimental groups (mean weight: group C, 1,720 g; group P, 1,800 g; and group G, $1740 \mathrm{~g}$ ).

Figure 1 shows the temporal pattern of the number of Eimeria spp. oocysts detected in the litter for each experimental group. From day 9 onwards, the OPG value in the litter was higher in the control group than in the other two groups.

Eimeria spp. oocysts were found in the intestinal contents of all the euthanized broilers of group C. Among the euthanized birds, i.e. in 12 (29\%) of group G and in 7 (17\%) of group P, no intestinal oocysts were detected.

Regarding the intensity of infection, the oocysts counts in group $\mathrm{C}$ were always significantly higher than in group $\mathrm{G}$, whereas differences between groups $\mathrm{C}$ and $\mathrm{P}$ were detected only on days 25 and 37. The intestinal OPG counts did not differ between groups $P$ and $G$ on day 25 , but significantly lower levels in $G$ than in P were detected on both day 10 and day 37 (Figure 2).

The coccidial lesion scores were always significantly higher in group $\mathrm{C}$ than in the other two groups. Comparable intestinal lesion scores in groups $\mathrm{P}$ and $\mathrm{G}$ were observed on both day 10 and day 37, whereas these two groups differed significantly on day 25 with lower levels detected among birds in group G (Figure 3).

In 14 birds (two on day 10, four on day 25 and eight at the end of the trial), all belonging to group $G$, enteritis was observed in the necropsies.

Coccidiostats for poultry are exclusively used as feed additives, and are mixed with compounded feeds in the producing feed mills upon request. Since 1971, with the introduction of monensin, 


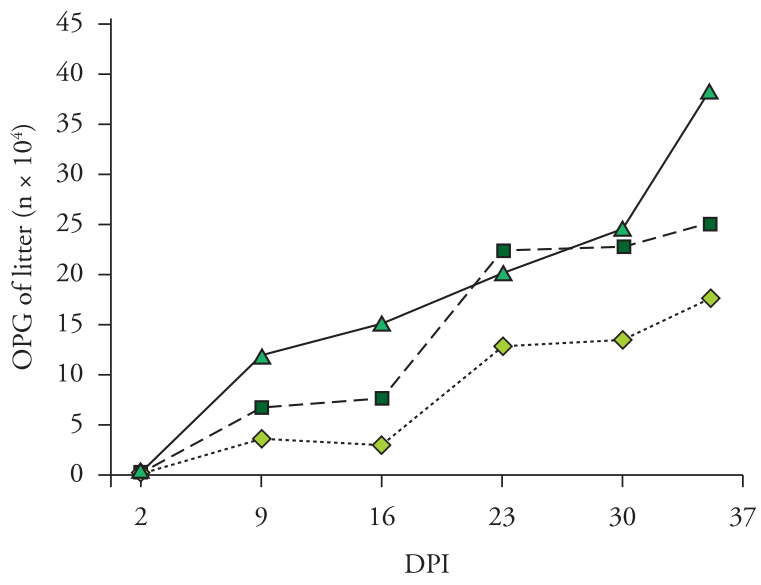

$\cdot \diamond \cdot$ group $\mathrm{P} \quad-\square \cdot \operatorname{group} \mathrm{G} \quad \triangle$ group $\mathrm{C}$

Figure 1. Number of Eimeria spp. oocysts per gram (OPG) of litter as a function of the number of days post-infection (DPI) for the two groups treated with monensin sodium (powdered, $\mathrm{P}$, and granulated, G), and the unmedicated control group (C).

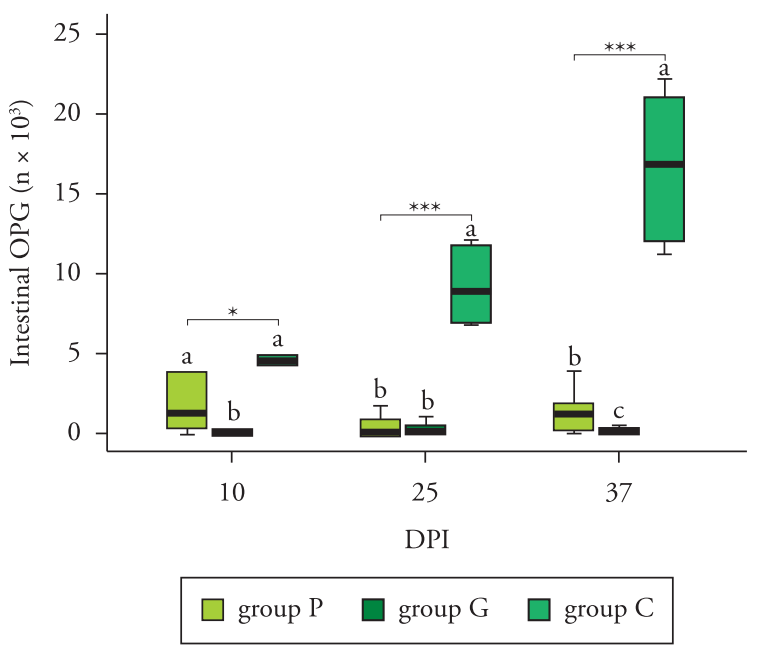

Figure 2. Variation in intestinal content of Eimeria spp. (oocysts per gram, OPG) in the groups treated with powdered $(\mathrm{P})$ and granulated $(\mathrm{G})$ monensin sodium, and in the unmedicated control group $(\mathrm{C})$ at 10, 25 and 37 days post-infection (DPI) (box-plots with median, 25 and $75 \%$ quartiles, minimum and maximum values). ${ }^{\mathrm{a}-\mathrm{c}}$ Different superscripts indicate statistically significant differences among the groups $\left({ }^{* *} \mathrm{p}<0.001,{ }^{* *} \mathrm{p}<0.01,{ }^{*} \mathrm{p}<0.05\right)$.

most commercial broilers have been medicated with this drug. The main reason for the popularity of monensin, apart from its high efficacy, is the relatively limited risk of complete resistance, at least compared with the risk of resistance towards synthetically produced drugs (PEEK; LANDMAN, 2003; WILLIAMS, 2006; JENKINS et al., 2010).

The granulated monensin formulation tested in this study was characterized by a particle size of 450-650 $\mu \mathrm{m}$. In comparison with powdered monensin formulations that are commonly used in commercial feed production, such increased particle sizes may present many advantages with regard to dispersion in cross-

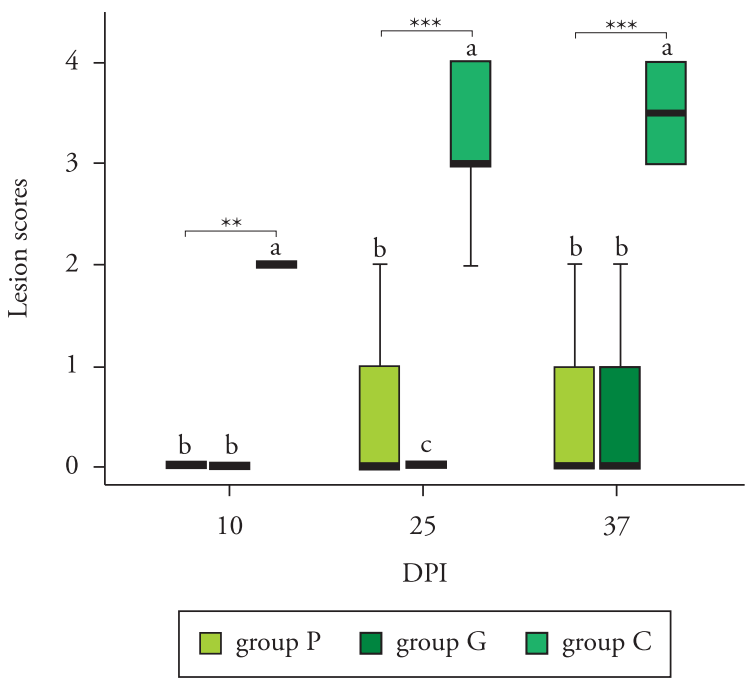

Figure 3. Variation in intestinal lesion scores in the groups treated with powdered $(\mathrm{P})$ and granulated $(\mathrm{G})$ monensin sodium, and in the unmedicated control group (C) at 10, 25 and 37 days post-infection (DPI) (box-plots with median, 25 and 75\% quartiles, minimum and maximum values). ${ }^{\mathrm{a}-\mathrm{c}}$ Different superscripts indicate statistically significant differences among the groups $\left({ }^{* * *} \mathrm{p}<0.001,{ }^{* *} \mathrm{p}<0.01\right.$, $\left.{ }^{*} \mathrm{p}<0.05\right)$.

contamination. As previously stated, the physical characteristics of additives, such as high dusting potential and small particle size, are a well-recognized problem in relation to cross-contamination of feed batches during the technical process of commercial feed production. Moreover, emission of monensin dust has to be taken into consideration in relation to handlers throughout the feed chain.

Although the dissolution rate of drugs is slower with larger particles, which is likely to result in lower bioavailability, our results showed that the efficacy of the granulated formulation against coccidia was comparable to that of the powdered formulation. As reported by Sigfridsson et al. (2011), since monensin is evenly absorbed over the entire intestinal tract, the rate of dissolution does not influence the extent of absorption.

Since enteritis was observed as a postmortem finding in some birds in group $G$, further studies will be needed in order to assess whether a correlation exists between the increased particle size of the drug and the enteric damage.

\section{Conclusion}

The granulated monensin sodium tested in this study was found to be very efficacious and comparable to the powdered formulation in controlling coccidiosis in broiler chickens. However, further investigations will be needed to assess whether the increased grain size of the drug might be the cause of the observed intestinal damage.

\section{Acknowledgements}

The authors would like to thank Dr. Joana Maria Venda da Graca Nery and Dr. Anna Rita Molinar Min for their technical support. 


\section{References}

Aarthi S, Dhinarki Raj G, Rman M, Gomathinayagam S, Kumanan K. Molecular prevalence and preponderance of Eimeria spp. among chickens in Tamil Nadu, India. Parasitol Res 2010; 107(4): 1013-1017. PMid:20607286. http://dx.doi.org/10.1007/s00436-010-1971-2

Chapman HD. Anticoccidial drugs and their effects upon the development of immunity to Eimeria infections in poultry. Avian Pathol 1999; 28(6): 521-535. PMid:16147561. http://dx.doi. org/10.1080/03079459994317

Dalloul RA, Lillehoj HS. Poultry coccidiosis: recent advancements in control measures and vaccine development. Expert Rev Vaccines 2006; 5(1): 143-163. PMid:16451116. http://dx.doi. org/10.1586/14760584.5.1.143

Du A, Hu S. Effects of a herbal complex against Eimeria tenella infection in chickens. JVet Med B 2004; 51(4):194-197. PMid:15228556. http:// dx.doi.org/10.1111/j.1439-0450.2004.00749.x

European Commission. Directive 2002/32/EC of the European Parliament and of the Council of 7 May 2002 on undesirable substances in animal feed. OffJ Eur Commun 2002; L140, 30.05.2002: 10.

European Commission. Directive 2009/8/EC of 10 February 2009 amending Annex I to Directive 2002/32/EC of the European Parliament and of the Council as regards maximum levels of unavoidable carryover of coccidiostats or histomonostats in non- target feed. Off J Eur Union 2009; L40: 19-25.

European Food Safety Authority - EFSA. Cross-contamination of nontarget feedingstuffs by monensin authorised for use as a feed additive. Scientific Opinion of the Panel on Contaminants in the Food Chain The EFSA Journal 2008; 592: 1-40.

Fincher JH. Particle size of drugs and its relationship to absorption and activity. J Pharmacol Sci 1968; 57(11): 1825-1835. PMid:4881918. http://dx.doi.org/10.1002/jps.2600571102

Freitas FLC, Almeida KS, Nascimento AA, Tebaldi JH, Machado RZ, Machado CR. Aspectos clínicos e patológicos em frangos de corte (Gallus gallus domesticus) infectados experimentalmente com oocistos esporulados de Eimeria acervulina TYZZER, 1929. Rev Bras Parasitol Vet 2008; 17(1): 16-20. PMid:18554435.

Hintz RJ, Johnson KC. The effect of particle size distribution on dissolution rate and oral absorption. Int J Pharmacol 1989; 51(1): 9-17. http://dx.doi.org/10.1016/0378-5173(89)90069-0

Holdsworth PA, Conway DP, McKenzie ME, Dayton AD, Chapman HD, Mathis GF, et al. World Association for the Advancement of Veterinary Parasitology (WAAVP) guidelines for evaluating the efficacy of anticoccidial drugs in chickens and turkeys. Vet Parasitol 2004; 121(3-4): 189-212. PMid:15135859. http://dx.doi. org/10.1016/j.vetpar.2004.03.006

International Federation for Animal Health Europe - IFAH. Report. [online]. 2007. Available from: http://www.ifaheurope.org/files/ifah/ documentslive/40/194_AR2007.pdf.

Jenkins M, Klopp S, Ritter D, Miska K, Fetterer R. Comparison of Eimeria species distribution and salinomycin resistance in commercial broiler operations utilizing different coccidiosis control strategies. Avian Dis 2010; 54(3): 1002-1006. PMid:20945780. http://dx.doi. org/10.1637/9137-111109-Reg.1

Johnson J, Reid WM. Anticoccidial drugs: Lesion scoring techniques in battery and floor-pen experiments with chickens.
Exp Parasitol 1970; 28(1): 30-36. http://dx.doi.org/10.1016/00144894(70)90063-9

Kaneniwa N, Watari N. Dissolution of slightly soluble drugs. IV. Effect of particle size of sulfonamides on in vitro dissolution rate and in vivo absorption rate, and their relation to solubility. Chem Pharm Bull 1978; 26(3): 813-826. http://dx.doi.org/10.1248/cpb.26.813

Kaneniwa N, Watari N, Iijima H. Dissolution of slightly soluble drugs. V. Effect of particle size on gastrointestinal drug absorption and its relation to solubility. Chem Pharm Bull 1978; 26(9): 2603-2614. http:// dx.doi.org/10.1248/cpb.26.2603

Kennedy DG, Hughes PJ, Blanchflower WJ. Ionophore residues in eggs in Northern Ireland: incidence and cause. Food Add Contam 1998; 15(5): 535-541. PMid:9829037. http://dx.doi. org/10.1080/02652039809374678

Lee BH, Kim WH, Jeong J, Yoo J, Kwon YK, Jung BY, et al. Prevalence and cross-immunity of Eimeria species on Korean chicken farms. J Vet Med Sci 2010; 72(8): 985-989. PMid:20234110. http://dx.doi. org/10.1292/jvms.09-0517

Lipinski CJ. Avoiding investment in doomed drugs. Is poor solubility an industry wide problem? Curr Drug Discov 2001; 4(1): 17-19.

Lipinski CJ. Poor aqueous solubility-an industry wide problem in drug discovery. American Pharmaceutical Review 2002; 5(1): 82-85.

Long PL, Rowell JG. Counting oocysts of chicken coccidia. Lab Practice 1958; 7: 515-518.

Lu ATK, Frisella ME, Johnson KC. Dissolution modeling: factors affecting the dissolution rates of polydisperse powders. Pharmacol Res 1993; 10(9): 1308-1314. PMid:8234168. http://dx.doi. org/10.1023/A:1018917729477

Peek HW, Landman WJ. Resistance to anticoccidial drugs of Dutch avian Eimeria spp. field isolates originating from 1996, 1999 and 2001. Avian Pathol 2003; 32(4): 391-401. PMid:17585463. http://dx.doi. org/10.1080/0307945031000121149

Sigfridsson K, Lundqvist AJ, Strimfors M. Particle size reduction and pharmacokinetic evaluation of a poorly soluble acid and a poorly soluble base during early development. Drug Dev Ind Pharm 2011; 37(3): 243 251. PMid:21073318. http://dx.doi.org/10.3109/03639045.2010.50 5927

Statistical Package for the Social Sciences - SPSS. User's guide, base 16.0 for Windows. Chicago: Statistical Package for Social Sciences. Inc.; 2007.

Story P, Doube A. A case of human poisoning by Salinomycin, an agricultural antibiotic. New Zeal Med J 2004; 117(1190): 799.

Strauch W. Causes and control of carry-over and cross-contamination (Part 1). Kraftfutter/Feed Magazine 2002a; 85(4): 151-159.

Strauch W. Causes and control of carry-over and cross-contamination (Part 2). Kraftfutter/Feed Magazine 2002b; 85(6): 239-24.

Strauch W. Is contamination-free feed production realistic? Feed Tech 2003; 7(7): 23-25.

Toledo GA, Almeida JDM, Almeida KS, Freitas FLC. Coccidiosis in broiler chickens raised in the Araguaína region, State of Tocantins, Brazil. Rev Bras Parasitol Vet 2011; 20(3): 249-252. http://dx.doi.org/10.1590/ S1984-29612011000300014

Williams RB. Tracing the emergence of drug-resistance in coccidia (Eimeria spp.) of commercial broiler flocks medicated with decoquinate for the first time in the United Kingdom. Vet Parasitol 2006; 135(1): 1-14. PMid:16289564. http://dx.doi.org/10.1016/j.vetpar.2005.10.012 